\title{
Effect of soil classes and climatic conditions on the productive characteristics and composition of Cabernet Sauvignon grapes
}

\author{
Maria Tereza Warmling ${ }^{1}$, Jackson Adriano Albuquerque ${ }^{2}$, \\ Maria Izabel Warmling ${ }^{3}$, Leo Rufato ${ }^{4}$, Jadiel Andognini ${ }^{5}$ \\ Abstract - Grapevines can be grown in different soil classes and climatic conditions. However, the \\ effect of these variables on grapevine and grape composition is complex. The aim of this study was \\ to evaluate the effect of soil classes and climatic conditions on productive and physico-chemical \\ characteristics and phenolic compounds of Cabernet Sauvignon grapes. The experiment was carried \\ out in São Joaquim (SC), located on the Southern Plateau of Santa Catarina. Cabernet Sauvignon \\ variety was analyzed in three soils (Dystrudepts, Humudepts and Rhodudalfs) and two harvests \\ (2015 and 2016). The climatic variables analyzed were rainfall, insolation and average, maximum \\ and minimum temperatures. Soil physical-chemical attributes, productive and physico-chemical \\ characteristics and phenolic compounds of grapes were analyzed. Both soil class and harvests had \\ significant effect on productive and physico-chemical characteristics and phenolic compounds of \\ grapes. Soil was more important for productive characteristics and phenolic compounds, while \\ meteorological conditions were more important for the physico-chemical characteristics of grapes. \\ Productive characteristics and grape composition were more adequate to wine production in the \\ 2016 harvest and in Rhodudalfs and Dystrudepts soil classes. \\ Index Terms: Viticulture. Vitis vinifera. Phenolic compounds. Anthocyanins.

\section{Efeito da classe de solo e das condições meteorológicas nas características produtivas e na composição da uva Cabernet Sauvignon}

Corresponding author: tetecav@gmail.com.br

Received: April 04, 2018. Accepted: August 30, 2018

Copyright: All the contents of this journal, except where otherwise noted, is licensed under a Creative Commons Attribution License.

\section{(cc) $\mathbf{E Y}$}

Resumo - As videiras podem ser cultivadas em diferentes solos e condições climáticas. Entretanto, o efeito destas variáveis na videira e na composição das uvas é complexo. O objetivo deste estudo foi avaliar o efeito das classes de solo e as condições meteorológicas nas características produtivas e na composição da uva Cabernet Sauvignon. O experimento foi implantado no município de São Joaquim, no Planalto Sul Catarinense. A cultivar foi da variedade Cabernet Sauvignon, cultivada em três solos (Cambissolo Háplico, Cambissolo Húmico e Nitossolo Bruno) e analisada por duas safras (2015 e 2016). As condições meteorológicas avaliadas foram a precipitação pluviométrica, a insolação e as temperaturas média, máxima e mínima. Nos solos, foram determinados os atributos físicos e químicos, e na videira, as características produtivas, físico-químicas e compostos fenólicos das uvas. Tanto a classe de solo como as safras tiveram efeito significativo nas características produtivas, físico-químicas e nos compostos fenólicos da uva. O solo foi mais importante para as características produtivas e compostos fenólicos, enquanto as condições meteorológicas foram mais importantes para as características físico-químicas da uva. As características produtivas e a composição da uva foram mais adequadas à produção de vinho na safra de 2016 e nas classes Nitossolo Bruno e Cambissolo Háplico.

Termos para indexação: Viticultura. Vitis vinífera. Compostos fenólicos. Antocianinas.

\footnotetext{
${ }^{1}$ Engenheira Agrônoma, Doutora em Ciência do Solo na Universidade do Estado de Santa Catarina, Avenida Luis de Camões, 2090, Conta Dinheiro, Lages-SC. Brasil. E-mail: tetecav@gmail.com.br

${ }^{2}$ Engenheiro Agrônomo, Professor Titular do Departamento de Solos e Recursos Naturais na Universidade do Estado de Santa Catarina. Brasil. E-mail: albuquerque@pq.cnpq.br

${ }^{3}$ Engenheira Agrônoma, Doutoranda do Programa de Pós Graduação em Ciência do Solo na Universidade do Estado de Santa Catarina, Brasil. E-mail: bel warmling@hotmail.com

${ }^{4}$ Engenheiro Agrônomo, Professor Titular do Departamento de Produção Vegetal na Universidade do Estado de Santa Catarina, Brasil. E-mail: leoruffato@ yahoo.com.br

${ }^{5}$ Engenheiro Agrônomo, Mestrando do Programa de Pós Graduação em Ciência do Solo na Universidade do Estado de Santa Catarina, Brasil. E-mail: jadi. andognini@gmail.com
} 


\section{Introduction}

The Southern Plateau of Santa Catarina stands out as an emerging pole of Brazilian viticulture, especially Vitis vinifera grape varieties (LOSSO, 2016). Cabernet Sauvignon stands out as one of the most cultivated varieties in the world, as it is used in the elaboration of fine wines. The typicity of wines from this variety is dependent on soil and climatic conditions, management, production and winemaking (ZOCCHE, 2009).

The climate has a strong influence in the other components of the natural environment, specifically in the interaction with soil as well as the cultivar and the vine cultivation techniques. In this way, grapes produced in the Southern Plateau of Santa Catarina show characteristics distinct from the other producing regions of Brazil, since summer is milder (TONIETTO and MANDELLI, 2003), which allows greater vegetative cycle, with complete phenological maturation and elaboration of fine wines (BRIGHENTI and TONIETTO, 2004; BORGHEZAN et al., 2011; LUCIANO, 2012).

Soil types directly influence grape and wine composition and are dependent on parent material and other soil forming factors. According to Van Leeuwen and Seguin (2006), in some regions, there is a strong correlation between geology and quality of wines produced. Soils with low weathering degree, younger (low effective depth), accumulate more water and are less suitable for the production of quality wines (VAN LEEUWEN and SEGUIN, 2006), producing wines of low alcoholic content and high acidity.

According to Luciano (2012), the Entisols and Inceptisols of the Southern Plateau of Santa Catarina have physico-hydrical and chemical restrictions for the implantation of altitude vineyards, since they have low effective depth of the profile, great stoniness and rock outcropping. Physico-hydrical attributes associated with vineyard management and the lower slope are often responsible for reducing the infiltration and translocation of water in the soil, which can restrict gas exchange between soil and atmosphere and percolation. Thus, vines implanted in relief and inappropriate soil can have excess water, which impairs the final quality of fruits (WUTKE et al., 2005).

Van Leeuwen et al. (2004) and Van Leeuwen and Seguin (2006) studied the relationship between climate conditions and grape composition in Bordeaux - France and Otago - New Zealand. In Brazil, Borghezan et al. (2011) evaluated the vegetative, productive behavior and composition of Cabernet Sauvignon grapes, relating them to the climate variables in different grapevine cycles. Luciano et al. (2013) evaluated two soils of mountainous region of SC cultivated with Cabernet Sauvignon and verified the effect of their characteristics on the levels of soluble solids, tannins, anthocyanins, titratable acidity and must $\mathrm{pH}$. They emphasized the importance of soil in grape composition for wine production.

The aim of this study was to evaluate the effect of soil classes and climatic conditions on productive and physico-chemical characteristics and phenolic compounds of Cabernet Sauvignon grapes grown on the Southern Plateau of Santa Catarina.

\section{Material and methods}

The experiment was carried out in a commercial vineyard implemented in 2002 with vines of Cabernet Sauvignon variety grafted on Paulsen 1103 (Vitis berlandieri $\mathrm{x}$ Vitis rupestris) in the training system Vertical Shoot Position, with spacing of $1.2 \mathrm{~m}$ between plants and $3 \mathrm{~m}$ between rows, and with anti-hail coverage in the municipality of São Joaquim, southern plateau of the state of Santa Catarina ( $28^{\circ} 15^{\prime \prime} 32^{\prime} \mathrm{S}$ and $49^{\circ} 57^{\prime}$ " 35 "W and average altitude of 1,260 $\mathrm{m}$ a.s.l.).

Vines were cultivated in three nearby areas but with different soils, and according to the Brazilian Soil Classification System (SANTOS et al., 2013) classified as Cambissolo Háplico Alítico típico, Cambissolo Húmico Alumínico típico e Nitossolo Bruno Distroférrico típico and in Soil Taxonomy (SOIL SURVEY STAFF, 2014) as Dystrudepts, Humudepts and Rhodudalfs, respectively (Table 1). Dystrudepts and Rhodudalfs are in steeper relief and have greater effective depth. Humudepts is in a flatter region, with lithic contact in depth near $50 \mathrm{~cm}$, making it poorly drained. In all areas, there was predominance of native plants managed through periodic mowing.

The harvests of 2015 and 2016 were evaluated. According to the Koppen classification, the local climate is $\mathrm{Cfb}$, humid mesothermic, without dry season and fresh summer. In the period between 1988 and 2016, annual averages of temperature, rainfall and relative humidity were equal to $14^{\circ} \mathrm{C}, 1800 \mathrm{~mm}$ and $82 \%$, respectively. July is the coldest month, characterized by an average historical temperature of $9.9^{\circ} \mathrm{C}$. The months with the lowest rainfall are April and May, with averages of 108 and $122 \mathrm{~mm}$, respectively, whereas the ones with the highest rainfall are September and October, with averages of 194 and 181 $\mathrm{mm}$, respectively (INMET, 2018). In some months there are temperatures below $0^{\circ} \mathrm{C}$, especially in June and July. In addition, late spring frosts occur with negative effects on grapevine budding (BORGHEZAN et al., 2014). Before vineyard implantation, the areas were maintained with natural pasture and, from 2000, they were prepared with plowing at $30 \mathrm{~cm}$ depth and harrowing. Then, soil acidity and fertility were corrected.

The choice of the three areas with different soils was made after the description and classification of profiles. In each area, 20 sample points were demarcated. For this, four planting rows spaced six meters between 
each other were selected. In each row, five points were demarcated, spaced $7.2 \mathrm{~m}$ apart, totaling an area of $24 \mathrm{x}$ $36 \mathrm{~m}\left(864 \mathrm{~m}^{2}\right)$. At each point, a small trench was opened for soil sampling. And at each point, two vines were demarcated for analysis of grape yield and composition.

Soil sampling was carried out in the planting row at $60 \mathrm{~cm}$ away from plants, because there are more roots in rows (LUCIANO, 2012). At each point, soil samples with preserved structure were collected at 0-10 and 10$20 \mathrm{~cm}$ layers. For this purpose, volumetric rings $\left(70 \mathrm{~cm}^{3}\right)$ were used. In the laboratory, samples were saturated for $48 \mathrm{~h}$ and submitted to tensions of 1,6 and $10 \mathrm{kPa}$ in sand tension table, and $30,100,300$ and $500 \mathrm{kPa}$ in Richards Chambers, obtaining the volumetric moisture at each tension. After this procedure, soil was oven dried (BLAKE and HARTGE, 1986). Water retention at 1,500 $\mathrm{kPa}$ was determined by the dew point technique using WP4 Dewpoint Potential Meter (DECAGON DEVICES, 2003). The soil water retention curve was adjusted to tension and volumetric moisture data pairs using the model proposed by Van Genuchten (1980). The curve was used to obtain the field capacity (moisture retained at $10 \mathrm{kPa}$ tension) and the permanent wilting point (moisture retained at $1,500 \mathrm{kPa}$ tension).

In addition, samples with altered structure were collected at $0-20 \mathrm{~cm}$ layer in the vine row, biweekly, from January to March, to determine gravimetric moisture. Volumetric moisture and water storage were calculated using bulk density and gravimetric moisture (LIBARDI, 2005).

In the 2015 and 2016 harvests, the following meteorological variables were evaluated: daily rainfall, insolation and average, maximum and minimum daily temperatures from December to April. Data are from a weather station near the vineyard and were provided by Epagri / Ciram.

Harvest was carried out in the maturation phase on March 30, 2015 and March 28, 2016. At each point in the two selected plants, four bunches were collected to determine the productive and physico-chemical characteristics and phenolic compounds of grapes. Productive characteristics were: number of bunches, bunch mass, rachis mass, bunch length, number of berries, mass of 50 berries and yield (considering planting density of 2,778 plants ha-1).

After determining the productive characteristics, 100 medium-size berries from the four bunches were selected. They were manually crushed to separate must and bark from grape berries. The must was used to determine soluble solids ( ${ }^{\circ}$ Brix), titratable acidity (meq $\mathrm{L}^{-1}$ ) and $\mathrm{pH}$ according to methodology proposed by the International Organization of Vine and Wine (OIV, 2009). Soluble solids were determined in digital refractometer. Titratable acidity was determined by titrating the must with $0.1 \mathrm{~N}$ sodium hydroxide and blue bromothymol as indicator. The $\mathrm{pH}$ was determined with potentiometer.

Bark was submitted to extraction according to Marcon Filho et al. (2015), which extract was used to determine color and concentration of total polyphenols and anthocyanins. The concentration of total polyphenols was determined by method described by Singleton and Rossi (1965) and anthocyanins and color were determined by method described by Rizzon (2010), using spectrophotometry.

The Kolmogorov-Smirnov test $(\mathrm{p}=0.05)$ was used to analyze the hypothesis of normality of data of productive and physico-chemical characteristics and phenolic compounds of grapes. When necessary, data were submitted to $\log$ transformation (y). Analysis of the variance was calculated considering the bifatorial experiment in the completely randomized design, with 20 replicates, with soil factors (three classes) and harvests (two harvests). Means were compared by Duncan ( $p=$ 0.05 ). In addition, the percentages of variance of each factor (soil and harvest) were calculated from the division between the sum of squares of each factor by the sum of total squares multiplied by 100 (UBALDE et al., 2010). The Statistical Analysis System software was used (SAS, 2003).

\section{Results and discussion}

Meteorological conditions differed between harvests, especially insolation (Table 2). In the final stage of grape maturation, rainfall was higher in the 2015 harvest. From January to March, the cumulative rainfall was $564 \mathrm{~mm}$ in 2015 and $457 \mathrm{~mm}$ in 2016 . The largest difference occurred in the first 30 days of the year, at the beginning of the stage of grape maturation, where precipitation was 264 in $2015 \mathrm{~mm}$ and $120 \mathrm{~mm}$ in 2016 (Figure 1). In 2015, rainfall was better distributed, while in 2016, two periods of lower water availability occurred in the second half of January and in first half of February (Figure 1), which resulted in lower soil water storage. In March, when harvest occurred, rainfall was similar between harvests, $149 \mathrm{~mm}$ in 2015 and $159 \mathrm{~mm}$ in 2016, but in the week prior to harvest, rainfall was $60 \mathrm{~mm}$ in 2015 and $44 \mathrm{~mm}$ in 2016 (Figure 1).

The total hours of annual insolation in vineyards influence the photosynthetic and metabolic activities of vines and, considering the quality of grapes, insolation has direct relation with temperature. Sentelhas (1998) suggests that vine needs between 1,200 and 1,400 hours of annual insolation to complete its cycle, depending on the variety. In the 2015 harvest, insolation was higher, but in the two harvests studied, vines had insolation hours over 1,400 hours per year. For the Cabernet Sauvignon variety, the shading of bunches reduces color, concentration of anthocyanins and soluble solids and increases acidity (IACONO et al., 1995). 
It was observed that, during the grape ripening, Humudepts had the highest water volume in the $0-20 \mathrm{~cm}$ soil layer and the Dystrudepts the lowest volume in both harvests evaluated (Figure 2). The largest water storage in the Humudepts in relation to the Dystrudepts and Rhodudalfs are mainly explained by the flatter relief, with lower slope and shallower profile. In addition, this soil has higher organic matter content, component with high water retention capacity (BRAIDA et al., 2011; KLEIN and KLEIN, 2015).

The water storage should be evaluated according to its availability, which refers to the difference between moisture in field capacity and the permanent wilting point. In both harvests, the average water storage in the three soils was between FC and PWP (Figure 2). Throughout the reproductive grapevine cycle, in both harvests, Humudepts had higher water storage compared to Rhodudalf and Dystrudepts (Figure 2) due to the previously mentioned factors such as relief, drainage and organic matter content in soil. In addition, greater spatial variability was observed in soil water storage, such as point six. Rhodudalfs has less variability in water storage among evaluated points. Another difference is that the water storage in Dystrudepts was closer to the PWP (except for points 8, 9, 10 and 11). This soil is in place that favors drainage.

Productive characteristics of Cabernet Sauvignon grape - All parameters were significantly affected by soil or harvest factors, except for rachis mass. Number of bunches, berry diameter, productivity and physico-chemical characteristics of grapes (acidity, $\mathrm{pH}$ and soluble solids) were more influenced by the harvest factor than by soil type. However, soil had greater effect than harvest on productivity characteristics (bunch length, bunch mass, rachis mass, number of berries and mass of 50 berries) and phenolic compounds (polyphenols, anthocyanins, color intensity and shade) (Table 3 ).

Considering the productive characteristics of Cabernet Sauvignon grape, it was observed that in Rhodudalf, variables bunch length, mass of 50 berries and berry diameter were higher when compared to Humudepts and Dystrudepts (Table 4). Variables bunch mass and yield were higher in Dystrudepts and Rhodudalfs when compared to Humudepts. Therefore, the productive characteristics of grapes were influenced by soil type, and the highest values were observed in Dystrudepts and Rhodudalfs, which are in the highest part of the vineyards, characterized as better drained soils, without water accumulation in the profile during rainy periods. Van Leeuwen et al. (2004) and Ubalde et al. (2010) also observed that the productive characteristics were significantly influenced by soil type, but not by climatic differences.

All productive variables, except for bunch length and rachis mass, were higher in the 2016 harvest, mainly explained by the better meteorological conditions occurred in this harvest, mainly at the final maturation stage of grapes, where lower rainfall was observed compared to the 2015 harvest (Figure 1).

More significant effects of the interaction were observed for mass of 50 berries and yield, which had, respectively, 28 and $30 \%$ of the variance percentage attributed to this interaction (Table 3 ).

Bunch mass, mass of 50 berries and berry diameter were higher in the 2016 harvest, components that positively influenced yield in this year. In the 2016 harvest, Rhodudalfs had higher yield, mass of 50 berries and berry diameter compared to the other two soils. These variables are very important because more productive systems are economically more viable. These variations occur due to several factors, which interact with each other and determine the vine yield components.

Humudepts had average yield of two crops $20 \%$ lower than Dystrudepts and 23\% lower than Rhodudalfs. It is soil with higher humidity, factor that can increase berry mass and diameter. Fregoni (1998) reports that there is an inverse correlation between sugar content and berry size and, for varieties intended to produce quality red wines, such as Cabernet Sauvignon, an excessive increase in berry size reduces must quality. Van Leeuwen et al. (2009) observed lower berry diameter in soils with lower water availability, which was also observed in the 2015 harvest due to the lower rainfall in the ripening phase (Figure 1 and Table 2). Brighenti et al. (2011) analyzed the performance of Cabernet Sauvignon variety with different rootstocks in São Joaquim and reported that water availability is an important factor for increasing berry size. The greater the amount of water available to the plant, the greater the berry size.

Luciano et al. (2013) also observed effect of soil $\mathrm{x}$ harvest interaction and attributed the lower yield of Humudepts to the lower soil drainage, which is located at lower elevation, with flatter relief, shallower profile, and higher organic matter content. On the other hand, Dystrudepts and Rhodudalfs are located in the highest part of vineyards, characterized as better drained soils, with no water accumulation in the profile during rainy periods, observed by their more vivid colors in horizons A and B (LUCIANO, 2012).

The productive characteristics were significantly higher in soils with lower water retention capacity and in harvest with lower rainfall in the maturation stage of grapes. This result is determined in part by the soil water regime (VAN LEEUWEN and SEGUIN, 1994). According to Van Leeuwen et al. (2003), more humid soils delay grape maturation. Wurz (2016) and Warmling (2017) evaluated the productive characteristics of Cabernet Sauvignon grapes and observed that the 2016 harvest stood out in relation to 2015 , producing grapes 
with better productive characteristics, which shows that the meteorological conditions positively influenced the productive characteristics, explained by the high rainfall in the stage of vegetative development and between flowering stage and color change of berries. Rainfall was better distributed in 2015, while in 2016, two lower water availability periods occurred in the second half of January and in the first half of February, which influenced the final quality of grapes produced in this harvest (Figure 1).

Thus, when analyzing yield-related parameters, it is observed that Rhodudalfs stood out from the others and Humudepts had the lowest yield (Table 4). This confirms the importance of soil type selection in grapevine cultivation, as reported by Luciano et al. (2013) in soils of Santa Catarina and Ubalde et al. (2010) in a study carried out in "Conca de Barbera" in Spain.

Physico-chemical characteristics of Cabernet Sauvignon grapes - When analyzing the physicochemical characteristics of Cabernet Sauvignon grapes, it was observed that grapes produced in Humudepts had higher acidity than those produced in Dystrudepts and higher $\mathrm{pH}$ in relation to the other soils (Table 4). However, the soluble solids content was higher in Dystrudepts and Rhodudalfs. An inverse relationship between $\mathrm{pH}$ and acidity and soluble solids was observed, which is considered ideal during the maturation process. Therefore, the physico-chemical characteristics of grape were influenced by soil type. However, a more evident effect occurred between harvests (Table 3 ).

In general, the cold climate of Southern Plateau of Santa Catarina region, where vineyards are located, causes the degradation of acids to be slower and, consequently, causes higher titratable acidity. There was a significant difference for titratable acidity in the 2016 harvest (157 meq $\left.\mathrm{L}^{-1}\right)$ compared to the 2015 harvest $\left(145 \mathrm{meq} \mathrm{L} \mathrm{L}^{-1}\right)$ (Table 4). Despite the significant difference, the amplitude of variation provided by soil and harvest factors was small.

Variables $\mathrm{pH}$ and soluble solids were influenced by soil $\mathrm{x}$ harvest interaction, which had, respectively, 25 and $30 \%$ of the variance percentage attributed to the interaction (Table 3). In the 2015 harvest, the must $\mathrm{pH}$ varied slightly among soil classes, but in the 2016 harvest, $\mathrm{pH}$ was higher than 3.5 in Rhodudalfs. In the mean of years, the 2016 harvest had higher must $\mathrm{pH}$ in the three soils (Figure 3 ). In studies conducted in the same region and with the same variety, Wurz (2016) observed $\mathrm{pH}$ close to 3.1 in the 2015 harvest and Warmling (2017), in vineyard implanted in Rhodudalfs, observed must $\mathrm{pH}$ close to 3.1 in the 2015 harvest and 3.5 in the 2016 harvest. According to Jackson (2014), must pH between 3.3 and 3.6 ensures better microbiological and physico-chemical stability for wines.

In the 2015 harvest, higher soluble solids content compared to the 2016 harvest was observed, with small variation among soils. However, in the 2016 harvest, Humudepts had lower soluble solids content compared to Dystrudepts and Rhodudalfs (Figure 3). According to Rosier (2006), sugar accumulation in grapes produced in regions of altitude varies from 16 to $20^{\circ}$ Brix. These lower sugar concentrations, compared to other grape and wine producing regions, are attributed to the climate. The low temperatures at the end of the ripening phase do not stimulate the production of sugars via hexoses, which favors the pentoses pathway in the production of phenolic compounds (ROSIER, 2006).

The physico-chemical characteristics of grapes showed differences in the harvests and soil classes, with soil factor having lower influence. Higher soluble solids content and lower acidity were observed in harvests with lower rainfall during the growth and maturation phase. These results can be explained by the effect of water limitation on plant hormonal balance and berry weight, which are responsible for directing sugar accumulation in grape (CHAMPAGNOL, 1984; BLOUIN and GUIMBERTEAU, 2004). The effect of harvest on the soluble solids content may be inversely related to the productive characteristics, that is, in the harvest with lower number of bunches and berries and bunch mass and mass of 50 berries, the soluble solids content was higher (Table $4)$.

Among the phenolic compounds of the Cabernet Sauvignon grape, it could be observed that in the Dystrudepts, polyphenol and anthocyanin contents and color intensity were higher, when compared to the other soil classes (Table 4). An inverse relationship between color intensity and shade was observed, which is considered ideal during the grape ripening phase. Therefore, the physico-chemical characteristics of grapes were influenced by soil type, with a more pronounced effect than the harvest (Table 3). There was no difference in total polyphenol content between harvests.

The anthocyanin content was higher in grapes cultivated in Dystrudepts compared to Rhodudalfs and Humudepts (Table 4). Felippeto et al. (2016) and Warmling (2017) studied the Cabernet Sauvignon variety in the region of São Joaquim in the 2015 harvest and observed anthocyanin contents of 128 and $138 \mathrm{mg} \mathrm{L}^{-1}$, respectively. Ubalde et al. (2010) observed that phenolic compounds were affected by harvest, but not by soil. Van Leeuwen et al. (2004) also observed a more pronounced soil effect. The highest contents of phenolic compounds were recorded in harvests with lower rainfall in the period prior to grape harvesting, possibly because of water limitation in the bark / berry ratio and consequently in the content of anthocyanins and polyphenols (ESTEBAN et al., 2001; GUROVICH and PAEZ, 2004). Thus, the lower rainfall occurred in the 2016 harvest in the ripening phase (January to March) (Figure 1) determined better phenolic maturation (higher anthocyanin content). 
The color intensity was higher in the Dystrudepts; however, this soil had the smallest color shade (Table 4). Warmling (2017) observed average color intensity of 7.0 in the 2015 harvest and 9.4 in the 2016 harvest, and mean color shade of 0.97 in the 2015 harvest and 0.93 in the 2016 harvest. Andres-de-Prado et al. (2007) compared grapes of Grenache cultivar in two soils and reported that better drained soils, with lower water storage and availability during the grape ripening phase presented higher color intensity and lower color shade, proportionally inverse ratios. Ubalde et al. (2010) studied interannual differences and observed higher color intensity in harvests with lower temperatures during the growing season and lower rainfall between maturation and harvest and in better drained soils.

According to Felippeto et al. (2016), climate is a factor of strong influence in the phenolic composition of grapes and these variations occur mainly due to the different meteorological conditions between harvests. The high concentration of anthocyanins and polyphenols observed in vineyards of high-altitude regions are related to low nocturnal temperatures, which reduce metabolic processes such as respiration and favor the accumulation of sugars and phenolic substances (ROSIER, 2006).

When analyzing harvests, most of the productive and qualitative characteristics of the grapes were highlighted in the 2016 harvest, except for soluble solids, which reinforces the effect of meteorological conditions on grape composition. In addition, vines produced grapes of better quality when implanted in Rhodudalfs and Dystrudepts. Considering the high rainfall that occurred in both years in which grapes in this experiment were produced (Table 2), these soil classes coming forward for with the best productive and physico-chemical characteristics and phenolic compounds, mainly due to their position in the landscape, which favors infiltration and / or flow of water in the soil profile after intense rains, unlike Humudepts, which is situated in lower position of the landscape, subject to periods of excess water due to poor drainage.

Table 1. Chemical and granulometric characterization, and total organic carbon content of Dystrudepts, Humudepts and Rhodudalfs adjacent to a commercial vineyard, São Joaquim (SC), 2011.

\begin{tabular}{|c|c|c|c|c|c|c|c|c|c|c|c|}
\hline \multicolumn{12}{|c|}{ Humudepts } \\
\hline Horiz. & Depth & \multicolumn{2}{|c|}{$\mathrm{pH}$} & Index & $\mathrm{P}$ & $\mathrm{K}$ & $\mathrm{Na}$ & $\mathrm{H}+\mathrm{Al}$ & $\mathrm{Al}$ & $\mathrm{Ca}$ & $\mathrm{Mg}$ \\
\hline & $\mathrm{cm}$ & water & $\mathrm{CaCl}_{2}$ & SMP & \multicolumn{3}{|c|}{--------mg kg-1------- } & \multicolumn{4}{|c|}{----- $\mathrm{cmol}_{\mathrm{c}} \mathrm{kg}^{-1}$----- } \\
\hline Ap & $0-15$ & 5.3 & 5.0 & 4.7 & 6.8 & 55 & 8 & 19.0 & 0.6 & 7.3 & 1.5 \\
\hline Ap2 & $15-33$ & 5.2 & 4.9 & 4.7 & 4.8 & 53 & 7 & 19.0 & 0.6 & 7.9 & 1.2 \\
\hline $\mathrm{AB}$ & $33-50$ & 4.9 & 4.7 & 4.4 & 1.6 & 37 & 5 & 17.9 & 3.2 & 1.8 & 0.5 \\
\hline $\mathrm{BC}$ & $66+$ & 4.5 & 4.5 & 4.1 & 0.1 & 21 & 5 & 12.5 & 4.8 & 1.0 & 0.2 \\
\hline Horiz. & Depth & \multicolumn{2}{|c|}{ Fine sand } & \multicolumn{2}{|c|}{ Coarse sand } & Silt & Clay & $\mathrm{OC}$ & \multicolumn{3}{|c|}{ Textural Class } \\
\hline Ap & $0-15$ & \multicolumn{2}{|c|}{40} & \multicolumn{2}{|c|}{110} & 530 & 330 & 78 & \multicolumn{3}{|c|}{ Silty clay } \\
\hline Ap2 & $15-33$ & \multicolumn{2}{|c|}{40} & \multicolumn{2}{|c|}{110} & 570 & 280 & 91 & \multicolumn{3}{|c|}{ Silty clay loam } \\
\hline $\mathrm{AB}$ & $33-50$ & \multicolumn{2}{|c|}{40} & \multicolumn{2}{|c|}{310} & 270 & 380 & 47 & \multicolumn{3}{|c|}{ Clay } \\
\hline $\mathrm{BC}$ & $66+$ & \multicolumn{2}{|c|}{30} & \multicolumn{2}{|c|}{70} & 260 & 640 & 35 & \multicolumn{3}{|c|}{ Clay } \\
\hline \multicolumn{12}{|c|}{ Dystrudepts } \\
\hline Horiz. & Depth & \multicolumn{2}{|c|}{$\mathrm{pH}$} & Index & $\mathrm{P}$ & $\mathrm{K}$ & $\mathrm{Na}$ & $\mathrm{H}+\mathrm{Al}$ & $\mathrm{Al}$ & $\mathrm{Ca}$ & $\mathrm{Mg}$ \\
\hline & $\mathrm{cm}$ & water & $\mathrm{CaCl}_{2}$ & SMP & \multicolumn{3}{|c|}{------- $\mathrm{mg} \mathrm{kg}^{-1}$-------- } & \multicolumn{4}{|c|}{------ $\mathrm{cmol}_{\mathrm{c}} \mathrm{kg}^{-1}$} \\
\hline A1 & $0-10$ & 5.2 & 4.9 & 5.1 & 2.1 & 84 & 0 & 11.9 & 0.3 & 4.0 & 1.4 \\
\hline A2 & $10-34$ & 4.6 & 4.6 & 4.3 & 0.6 & 48 & 0 & 14.8 & 7.0 & 1.6 & 0.3 \\
\hline $\mathrm{BC}$ & $34-60$ & 4.8 & 4.7 & 3.9 & 1.2 & 46 & 0 & 15.8 & 10.1 & 1.8 & 0.4 \\
\hline $\mathrm{Cr}$ & $60-80$ & 4.6 & 4.6 & 3.6 & 0.2 & 72 & 2 & 19.7 & 17.3 & 5.0 & 1.6 \\
\hline $\mathrm{C}$ & $80+$ & 4.6 & 4.5 & 3.6 & 0.6 & 86 & 5 & 21.8 & 21.1 & 7.2 & 2.6 \\
\hline Horiz. & Depth & \multicolumn{2}{|c|}{ Fine sand } & \multicolumn{2}{|c|}{ Coarse sand } & Silt & Clay & $\mathrm{OC}$ & \multicolumn{3}{|c|}{ Textural Class } \\
\hline A1 & $0-10$ & \multicolumn{2}{|c|}{70} & \multicolumn{2}{|c|}{190} & 340 & 400 & 70 & \multicolumn{3}{|c|}{ Clay } \\
\hline A2 & $10-34$ & \multicolumn{2}{|c|}{50} & 18 & & 280 & 490 & 44 & & Clay & \\
\hline $\mathrm{BC}$ & $34-60$ & & & 11 & & 320 & 510 & 25 & & Clay & \\
\hline $\mathrm{Cr}$ & $60-80$ & & & 40 & & 560 & 340 & 17 & & y cla & \\
\hline $\mathrm{C}$ & $80+$ & & & 20 & & 820 & 90 & 12 & & loa & \\
\hline
\end{tabular}




\begin{tabular}{|c|c|c|c|c|c|c|c|c|c|c|c|}
\hline Horiz. & Depth & \multicolumn{2}{|c|}{$\mathrm{pH}$} & Index & $\mathrm{P}$ & $\mathrm{K}$ & $\mathrm{Na}$ & $\mathrm{H}+\mathrm{Al}$ & $\mathrm{Al}$ & $\mathrm{Ca}$ & $\mathrm{Mg}$ \\
\hline & $\mathrm{cm}$ & water & $\mathrm{CaCl}_{2}$ & SMP & \multicolumn{3}{|c|}{------- $\mathrm{mg} \mathrm{kg}^{-1}$------- } & \multicolumn{4}{|c|}{------- cmol kg-1 $^{-1}$------- } \\
\hline A & $0-29$ & 4.7 & 4.6 & 4.6 & 3.9 & 97 & 10 & 16.1 & 3.4 & 1.2 & 0.2 \\
\hline $\mathrm{AB}$ & $29-53$ & 4.7 & 4.6 & 4.7 & 0.2 & 24 & 4 & 11.9 & 2.4 & 0.5 & 0.1 \\
\hline BA & $53-75$ & 4.7 & 4.6 & 4.7 & 1.0 & 14 & 0 & 11.3 & 2.6 & 0.3 & 0.1 \\
\hline B & $75+$ & 4.8 & 4.7 & 4.4 & 1.0 & 19 & 0 & 11.6 & 3.6 & 0.4 & 0.1 \\
\hline $\mathrm{C}$ & & 4.8 & 4.7 & 4.3 & 1.0 & 17 & 0 & 11.3 & 4.2 & 0.4 & 0.1 \\
\hline Horiz. & Depth & \multicolumn{2}{|c|}{ Fine sand } & \multicolumn{2}{|c|}{ Coarse sand } & Silt & Clay & $\mathrm{OC}$ & \multicolumn{3}{|c|}{ Textural Class } \\
\hline A & $0-29$ & \multicolumn{2}{|c|}{50} & \multicolumn{2}{|c|}{120} & 310 & 520 & 76 & \multicolumn{3}{|c|}{ Clay } \\
\hline $\mathrm{AB}$ & $29-53$ & \multicolumn{2}{|c|}{40} & \multicolumn{2}{|c|}{130} & 290 & 540 & 47 & \multicolumn{3}{|c|}{ Clay } \\
\hline BA & $53-75$ & \multicolumn{2}{|c|}{50} & \multicolumn{2}{|c|}{60} & 290 & 600 & 30 & \multicolumn{3}{|c|}{ Clay } \\
\hline B & $75+$ & \multicolumn{2}{|c|}{40} & \multicolumn{2}{|c|}{50} & 240 & 670 & 29 & \multicolumn{3}{|c|}{ Clay } \\
\hline $\mathrm{C}$ & & \multicolumn{2}{|c|}{70} & \multicolumn{2}{|c|}{30} & 400 & 500 & 16 & \multicolumn{3}{|c|}{ Clay } \\
\hline
\end{tabular}

*Horiz = Horizon; $\mathrm{P}=$ Phosphorus $\mathrm{K}=$ Potassium; $\mathrm{Na}=$ Sodium $\mathrm{H}+\mathrm{Al}=$ Hydrogen + Aluminum; $\mathrm{Al}=\mathrm{Aluminum} ; \mathrm{Ca}=\mathrm{Calcium} ; \mathrm{Mg}=$ Magnesium; granulometry $\left(\mathrm{g} \mathrm{kg}^{-1}\right) ; \mathrm{OC}=$ Organic carbon $\left(\mathrm{g} \mathrm{kg}^{-1}\right)$. Profile described and collected by Rodrigo Vieira Luciano.

Table 2. Minimum, average and maximum temperatures, thermal amplitude, insolation, rainfall and cold hours in budding and Veraison periods (September - January), during the grape ripening phase (February - March), and annual in the South Plateau of SC, 2016.

\begin{tabular}{|c|c|c|c|c|c|c|c|c|c|c|c|c|}
\hline \multirow[b]{2}{*}{ Harvest } & \multicolumn{3}{|c|}{$\begin{array}{c}\text { Minimum Temperature } \\
\left({ }^{\circ} \mathrm{C}\right)\end{array}$} & \multicolumn{3}{|c|}{$\begin{array}{c}\text { Mean Temperature } \\
\left({ }^{\circ} \mathrm{C}\right)\end{array}$} & \multicolumn{3}{|c|}{$\begin{array}{c}\text { Maximum Temperature } \\
\left({ }^{\circ} \mathrm{C}\right)\end{array}$} & \multicolumn{3}{|c|}{$\begin{array}{l}\text { Thermal Amplitude } \\
\left({ }^{\circ} \mathrm{C}\right)\end{array}$} \\
\hline & Sep-Jan & Feb-Mar & Years & Sep-Jan & Feb-Mar & Years & Sep-Jan & Feb-Mar & Years & Sep-Jan & Feb-Ma & Years \\
\hline $2014 / 2015$ & 11.0 & 11.8 & 9.7 & 15.7 & 16.5 & 14.2 & 21.2 & 21.9 & 19.2 & 10.2 & 10.1 & 9.5 \\
\hline \multirow[t]{2}{*}{$2015 / 2016$} & 11.3 & 12.9 & 10.1 & 15.4 & 16.9 & 14.1 & 20.4 & 22.1 & 19.1 & 9.1 & 9.2 & 9.0 \\
\hline & \multicolumn{4}{|c|}{ Insolation (h) } & \multicolumn{3}{|c|}{ Rainfall (mm) } & \multicolumn{3}{|c|}{ Cold (h) } & & \\
\hline Harvest & & Sep-Jan F & eb-Mar & Years & Sep-Jan & $\begin{array}{l}\text { Feb- } \\
\text { Mar }\end{array}$ & Years & Sep-Jan & Feb-Mar & Years & & \\
\hline $2014 / 2015$ & & 866 & 379 & 2.008 & 1.089 & 300 & 2.373 & 119 & 0 & 792 & & \\
\hline $2015 / 2016$ & & 699 & 341 & 1.744 & 1.225 & 337 & 2.224 & 152 & 1 & 733 & & \\
\hline
\end{tabular}

*Set - Jan = September - January; Feb - Mar = February - March; Data provided by CIRAN - EPAGRI, 2016. Source: author, 2018. 
Table 3 - Variance percentage, average of two harvests, attributed to soil, harvest and soil $\mathrm{x}$ harvest interaction for the productive and physico-chemical characteristics, and phenolic compounds of Cabernet Sauvignon variety cultivated in the Southern Plateau of SC, 2016.

\begin{tabular}{|c|c|c|c|}
\hline & Soil & Harvest & Soil x Harvest \\
\hline & \multicolumn{3}{|c|}{-----------....\%o-----------.... } \\
\hline Number of bunches & $47^{\mathrm{ns}}$ & $48^{* *}$ & $5^{\mathrm{ns}}$ \\
\hline Bunch length (cm) & $84^{* *}$ & $0^{\text {ns }}$ & $16^{\mathrm{ns}}$ \\
\hline Rachis mass (g) & $71^{\mathrm{ns}}$ & $8^{\text {ns }}$ & $21^{\text {ns }}$ \\
\hline Bunch mass (g) & $57^{* *}$ & $26^{* *}$ & $17^{*}$ \\
\hline Mass of 50 bunches $(\mathrm{g})$ & $53^{* *}$ & $19^{* *}$ & $28^{* *}$ \\
\hline Berry diameter (mm) & $11^{*}$ & $80^{* *}$ & $9^{*}$ \\
\hline Number of berries & $54^{* *}$ & $33^{* *}$ & $13^{\mathrm{ns}}$ \\
\hline Yield $\left(\mathrm{t} \mathrm{ha}^{-1}\right)$ & $17^{*}$ & $53^{* * *}$ & $30^{* *}$ \\
\hline Acidity $\left(\right.$ meq L L $\left.{ }^{-1}\right)$ & $23^{*}$ & $50^{* *}$ & $27^{\mathrm{ns}}$ \\
\hline Must $\mathrm{pH}$ & $26^{* *}$ & $49^{* *}$ & $25^{* *}$ \\
\hline Soluble solids ( ${ }^{\circ}$ Brix) & $25^{\text {** }}$ & $45^{* *}$ & $30^{* *}$ \\
\hline Polyphenols (mg L-1) & $91^{* *}$ & $1^{\text {ns }}$ & $8^{\mathrm{ns}}$ \\
\hline Anthocyanins (mg L-1) & $85^{* *}$ & $12^{* *}$ & $3^{\text {ns }}$ \\
\hline Intensity & $49^{* *}$ & $46^{* *}$ & $5^{\text {ns }}$ \\
\hline Color shade & $77^{* *}$ & $19^{*}$ & $4^{\mathrm{ns}}$ \\
\hline
\end{tabular}

a-Significant at $1 \%$ probability level $(\mathrm{p}<0.01)$; ${ }^{*}$ significant at $5 \%$ probability level $(0.01 \leq \mathrm{p}<0.05)$ and ns non-significant $(\mathrm{p} \geq 0.05)$

Table 4 - Effect of soil and harvest on productive and physico-chemical characteristics, and phenolic compounds of Cabernet Sauvignon grapes grafted on Paulsen 1103 in the municipality of São Joaquim, Santa Catarina.

\begin{tabular}{|c|c|c|c|c|c|c|c|}
\hline \multirow[b]{3}{*}{ Number of bunches } & \multicolumn{3}{|c|}{ Soil } & \multicolumn{4}{|c|}{ Harvest } \\
\hline & Humudepts & Dystrudepts & Rhodudalfs & 2015 & & 2016 & \\
\hline & $26.0 \mathrm{~ns}$ & 25.0 & 27.0 & 23.0 & $\mathrm{~b}$ & 30.0 & $a$ \\
\hline Bunch length (cm) & $14.0 \mathrm{~b}$ & $15.0 \mathrm{~b}$ & $17.0 \mathrm{a}$ & 15.4 & $\mathrm{~ns}$ & 15.4 & \\
\hline Rachis mass (g) & $5.0 \mathrm{~ns}$ & 5.4 & 5.8 & 5.3 & $\mathrm{~ns}$ & 5.5 & \\
\hline Bunch mass (g) & $104.0 \mathrm{~b}$ & $138.0 \mathrm{a}$ & $128.0 \mathrm{a}$ & 113.0 & $\mathrm{~b}$ & 133.0 & $\mathrm{a}$ \\
\hline Mass of 50 bunches $(\mathrm{g})$ & $64.5 \mathrm{c}$ & $69.6 \mathrm{~b}$ & 73.4 a & 66.9 & $\mathrm{~b}$ & 71.4 & $\mathrm{a}$ \\
\hline Berry diameter (mm) & $12.5 \mathrm{~b}$ & $12.5 \mathrm{~b}$ & $12.9 \mathrm{a}$ & 12.1 & $\mathrm{~b}$ & 13.2 & $\mathrm{a}$ \\
\hline Number of berries & $81.0 \mathrm{~b}$ & $99.0 \mathrm{a}$ & $87.0 \mathrm{~b}$ & 83.0 & $\mathrm{~b}$ & 95.0 & $\mathrm{a}$ \\
\hline Yield $\left(\mathrm{t} \mathrm{ha}^{-1}\right)$ & $7.8 \mathrm{~b}$ & $9.7 \mathrm{a}$ & $10.1 \mathrm{a}$ & 7.4 & $\mathrm{~b}$ & 10.9 & $\mathrm{a}$ \\
\hline Acidity $\left(\mathrm{meq} \mathrm{L}^{-1}\right)$ & 156 & 147 & 150 & 145 & $\mathrm{~b}$ & 157 & $\mathrm{a}$ \\
\hline Must pH & $3.3 \mathrm{a}$ & $3.2 \mathrm{~b}$ & $3.1 \mathrm{c}$ & 3.1 & $\mathrm{~b}$ & 3.3 & $\mathrm{a}$ \\
\hline Soluble solids ( $\left({ }^{\circ} \mathrm{Brix}\right)$ & $19.6 \mathrm{~b}$ & 20.4 a & $20.3 \mathrm{a}$ & 20.6 & $\mathrm{a}$ & 19.6 & $\mathrm{~b}$ \\
\hline Polyphenols & 877 & 1257 & 1064 & 1051 & $\mathrm{~ns}$ & 1081 & \\
\hline Anthocyanins (mg L-1) & 120 & 171 & 128 & 131 & $\mathrm{~b}$ & 148 & $\mathrm{a}$ \\
\hline Intensity & $8.5 \mathrm{~b}$ & $10.4 \mathrm{a}$ & $8.1 \mathrm{~b}$ & 8.0 & $\mathrm{~b}$ & 9.9 & $\mathrm{a}$ \\
\hline Color shade & $1.0 \mathrm{a}$ & $0.83 \mathrm{~b}$ & $1.0 \mathrm{a}$ & 1.0 & $\mathrm{a}$ & 0.9 & $\mathrm{~b}$ \\
\hline
\end{tabular}

*-ns - averages followed by the same letter do not differ statistically from each other. Testing averages compare soils and the differences between classes are represented by letters in rows. Differences between harvests are also represented in the row. The Duncan test was applied at $5 \%$ probability level $(0.01 \leq \mathrm{p}<0.05)$. 

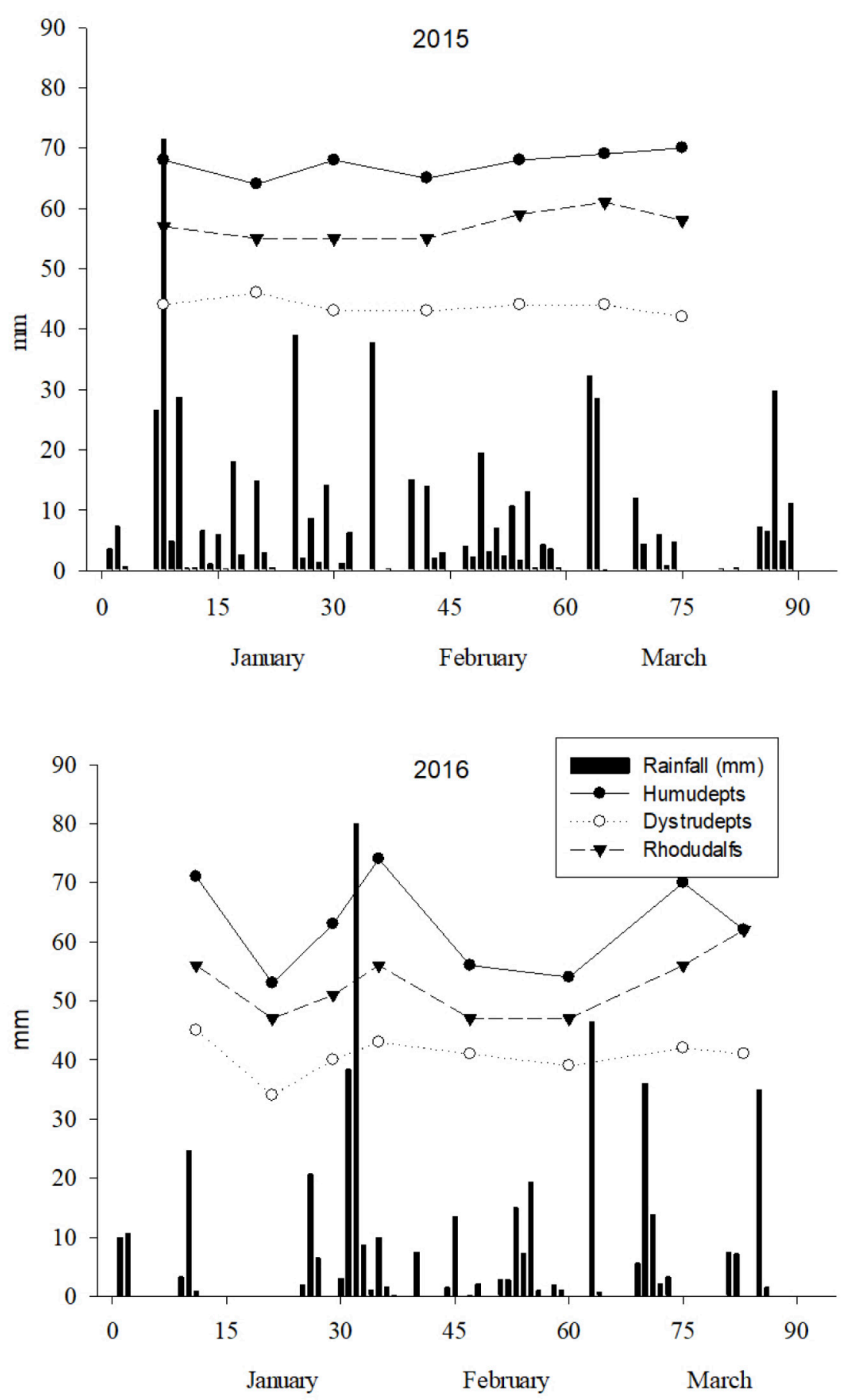

Figure 1. Rainfall ( $\mathrm{mm}$ ) represented by columns, and water storage at the 0-20 $\mathrm{cm}$ soil layer $(\mathrm{mm})$ represented in horizontal lines, from January to March, in the 2015 and 2016 harvests, in three soil classes in the Southern Plateau of SC. (Water storage averages correspond to 20 points of each soil). 


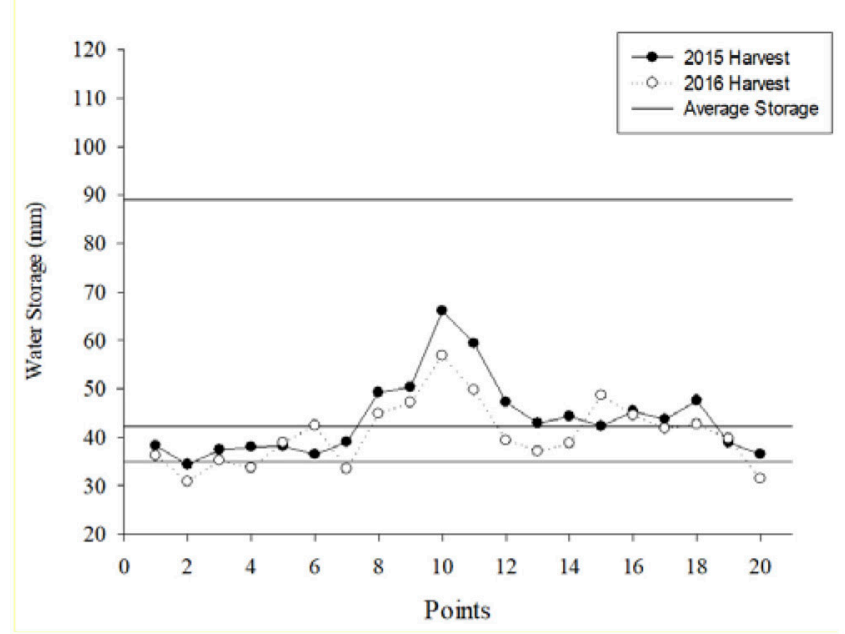

Dystrudepts

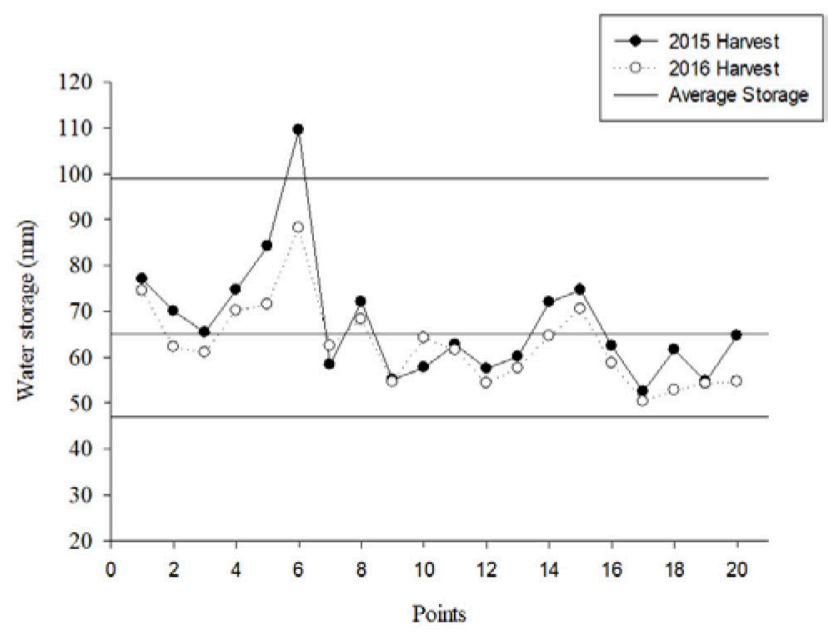

Humudepts

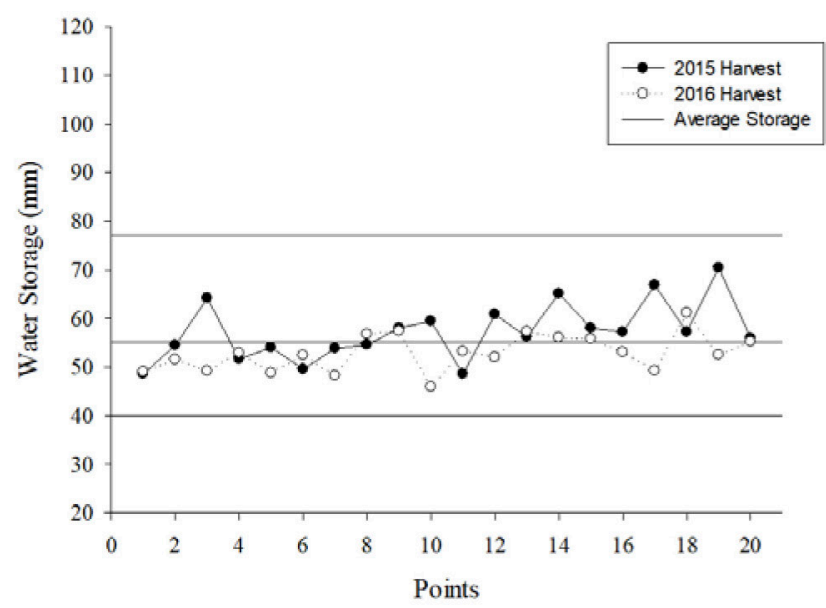

Rhodudalfs

Figure 2 .Water storage at the $0-20 \mathrm{~cm}$ soil layer (mm), average collection dates (seven in 2015 and eight in 2016), in the 20 points of the study areas in the 2015 and 2016 harvests in the three evaluated soils. 


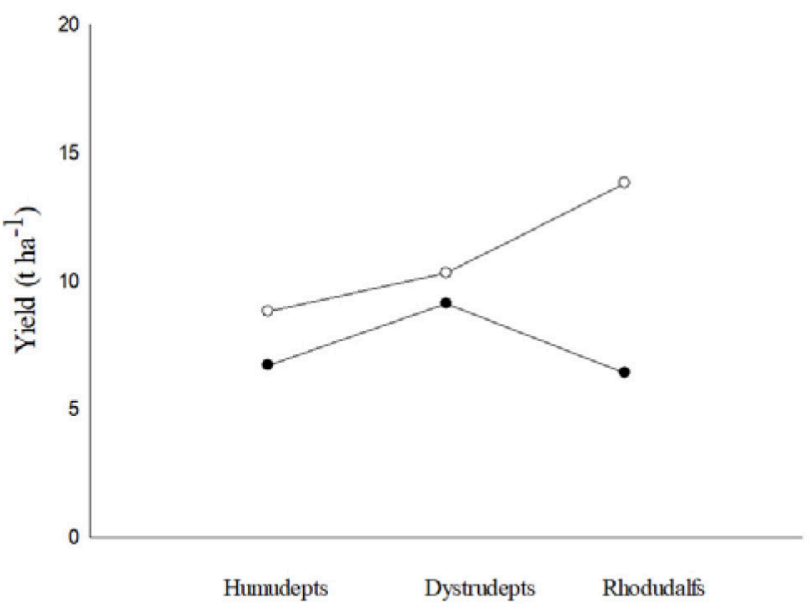

A
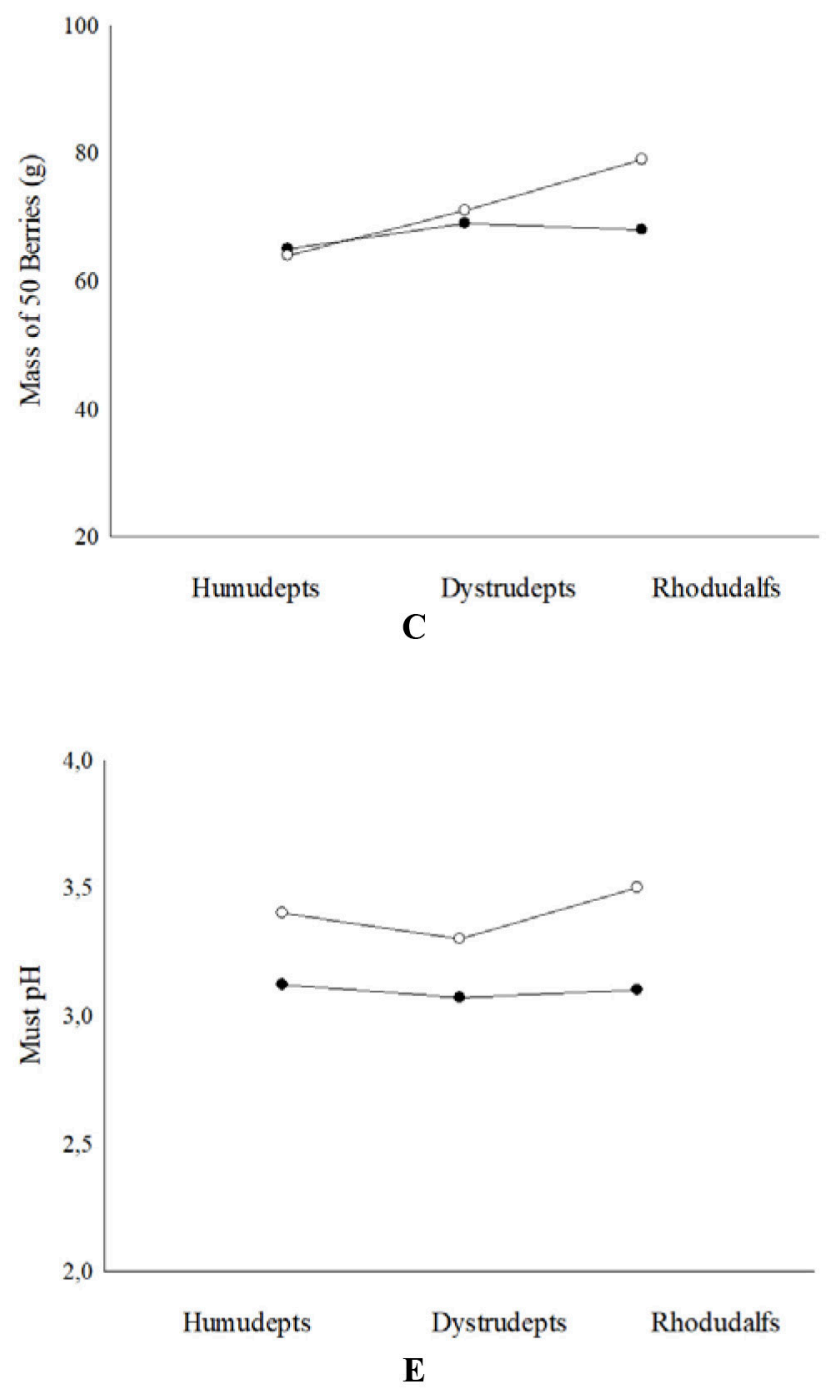
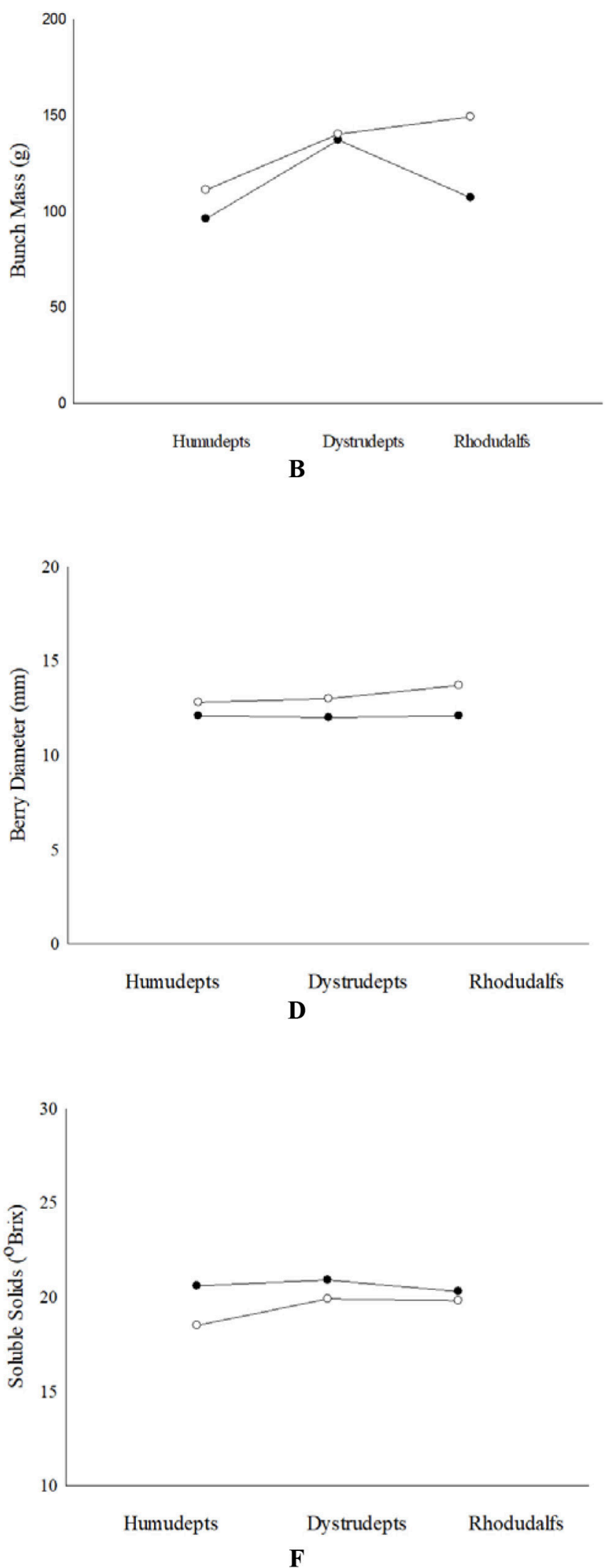

Figure 3. Soil x harvest interaction in variables (A) yield (ton ha $\left.{ }^{-1}\right)$; (B) bunch mass (g); (C) mass of 50 berries (g); (D) berry diameter $(\mathrm{mm})$; (E) must $\mathrm{pH}$; and (F) soluble solids. Capital letters compare harvests and lowercase compare soil classes. 


\section{Conclusion}

In general, the productive and qualitative characteristics of Cabernet Sauvignon grapes were more adequate in Rhodudalfs and Dystrudepts classes, characterized by the better water drainage in the soil profile.

The grape composition is influenced by climatic conditions and consequently by interannual variability. The 2016 harvest presented better productive and physicochemical characteristics and phenolic compounds of grapes.

\section{References}

ANDRÉS-DE PRADO, R.; YUSTE-ROJAS, M.; SORT, X.; ANDRÉS-LACUEVA, C.; TORRES, M.; LAMUELA-RAVENTÓS, R. M. Effect of soil type on wines produced from Vitis vinifera L. cv. Grenache in commercial vineyards. Journal of Agricultural and Food Chemistry, Washington, v.55, n.3, p.779- 786, 2007.

BLAKE, G.R.; HARTGE, K.H. Bulk density. In: KLUTE, A. (Ed.). Methods of soil analysis: physical and mineralogical methods. $2^{\text {nd }}$ ed. Madison: American Society of Agronomy, 1986. p. 363-375.

BLOUIN, J.; GUIMBERTEAU, G. Maduración y madurez de la uva. Madrid: Ediciones Mundi-Prensa, 2004. 151p.

BORGHEZAN, M.; GAVIOLI, O.; PIT, F.A.; SILVA, A.L. Comportamento vegetativo e produtivo da videira e composição da uva em São Joaquim, Santa Catarina. Pesquisa Agropecuária Brasileira, Brasília, DF, v.46, n.4, p.398-405, 2011. Disponível em: $<$ http://www.scielo. br/pdf/pab/v46n4/09.pdf > . Acesso em: 17 abr. 2017.

BORGHEZAN, M.; VILLAR, L.; SILVA, T.C.; CANTON, M.; GUERRA, M.P.; CAMPOS, C.G.C. Phenology and vegetative growth in a new production region of grapevines: case study in São Joaquim, Santa Catarina, Southern Brazil. Open Journal of Ecology, Hubei Province, v.4, n.6, p.321-335, 2014. Disponível em: $<$ http://file.scirp.org/pdf/OJE_2014052313344402.pdf $>$. Acesso em: 30 mai. 2017.

BRAIDA, J.A.; BAYER, C.; ALBUQUERQUE, J.A.; REICHERT, J.M. Matéria orgânica e seu efeito na física do solo. In: SBCS. Tópicos em ciência do solo. Viçosa: Sociedade Brasileira de Ciência do Solo, 2011. v.7, p. 221-278.
BRIGHENTI, A.F.; RUFATO, L.; KRETZSCHMAR, A.A.; SCHLEMPER, C. Desempenho vitivinícola da Cabernet Sauvignon sobre diferentes porta-enxertos em região de altitude de Santa Catarina. Revista Brasileira de Fruticultura, Jaboticabal, v.33, n.1, p.96-102, 2011. Disponível em: < http://www.scielo.br/pdf/rbf/v33n1/ aop02211.pdf > . Acesso em: 14 fev. 2017.

BRIGHENTI, E.; TONIETTO, J. O clima de São Joaquim para a viticultura de vinhos finos: classificação pelo Sistema CCM Geovitícola. In: CONGRESSO BRASILEIRO DE FRUTICULTURA, 18., 2004, Florianópolis. Anais... Florianópolis: SBF, 2004. CD-ROM.

CHAMPAGNOL, F. Éléments de physiologie de la vigne et de viticulture générale. Saint-Gely-du- Fesc: François Champagnol, 1984. 351p.

Decagon Devices, Inc. Operator's manual version 3 WP4 Dewpoint PotentiaMeter. Pulmann: Decagon Devices, 2003. 77p.

ESTEBAN, M.; VILLANUEVA, M.J.; LISSARRAGUE, J.R. Effect of irrigation on changes in the anthocyanin composition of the skin of cv. Tempranillo (Vitis vinifera L.) grape berries during ripening. Journal of the Science of Food and Agriculture, New York, v.81, n.4, p.409420, 2001.

FELIPPETO, J.; ALEMBRANDT, R.; CIOTTA, M.N. Maturação e composição das uvas Cabernet Sauvignon e Merlot produzidas na região de São Joaquim, SC. Agropecuária Catarinense, Florianópolis, v.29, n.2, p.74-79, 2016. Disponível em: $<$ http://publicacoes.epagri. sc.gov.br/index.php/RAC/article/viewFile/72/11>. Acesso em: 8 jan. 2018.

FREGONI, M. Viticoltura di qualitá. Verona: Edizione I'Informatore Agrário, 1998. 707p.

GUROVICH, L.A.; PA'EZ, C.I. Influencia del riego deficitario controlado sobre el desarrollo de las bayas y la composición química de los mostos y vinos. Ciencia e Investigación Agraria, Santiago, v.31, n.3, p.175-186, 2004.

IACONO, F.; BERTAMINI, M.; SCIENZA,A.; COOMBE, B.G. Differential effects of canopy manipulation and shading of Vitis vinifera L. cv. Cabernet Sauvignon. I. Composition of grape berries. Viticulture and Enology Science, Davis, v.34, n.4, p.201-226, 1995. 
INMET. Rede de estações climatológicas. Brasília, DF: Instituto Nacional de Meteorologia. 2018. Disponível em: $<$ http://www.inmet.gov.br/portal/index.php?r=home/ index >. Acesso em: 12 fev. 2018.

JACKSON, R.S. Wine science: principles and applications. $4^{\text {th }}$ ed. Amsterdam: Elsevier, 2014. 751p.

KLEIN, C.; KLEIN, V.A. Estratégias para potencializar a retenção e disponibilidade de água no solo. Revista Ciência e Natura, Santa Maria, v.19, n.1, p.21-29, 2015. Disponível em: $<\underline{\text { https://periodicos.ufsm.br/reget/article/ }}$ viewFile/14990/pdf>. Acesso em: 19 abr. 2018.

LIBARDI, P.L. Dinâmica da água no solo. São Paulo: Edusp, 2005. 344p.

LOSSO, F. B. A vitivinicultura de altitude em Santa Catarina: Desafios para o desenvolvimento do enoturismo. 2016. $307 \mathrm{f}$. Tese (Doutorado em Geografia) - Universidade Federal de Santa Catarina, Florianópolis, 2016.

LUCIANO, R.V. Variabilidade espacial e temporal de atributos do solo e sua relação com a composição da uva para vinificação no Planalto Catarinense. 2012. 139 f. Tese (Doutorado em Ciência do Solo) - Universidade do Estado de Santa Catarina, Florianópolis, 2012.

LUCIANO, R.V.; ALBUQUERQUE, J.A.; RUFATO, L.; MIQUELUTTI, D.J.; WARMLING, M.T. Condições meteorológicas e tipo de solo na composição da uva 'Cabernet Sauvignon'. Pesquisa Agropecuária Brasileira, Brasília, DF, v.48, n.1, p.97-104, 2013.

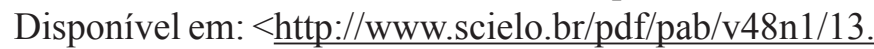
pdf $>$. Acesso em: 11 dez. 2017.

MARCON FILHO, J.L.; HIPÓLITO, J.S.; MACEDO, T.A.; FRETZCHMAR, A.A; RUFATO, L. Raleio de cachos sobre o potencial enológico da uva 'Cabernet Franc' em duas safras. Ciência Rural, Santa Maria, v.45, n.12, p.2150-2156, 2015. Disponível em: <http://www.scielo. br/pdf/cr/v45n12/1678-4596-cr-0103 8478cr20140995. pdf > . Acesso em: 9 out. 2016.

OIV -. Office International de la Vigne et du Vin. Recueil des méthodes internationales d'analyse des vins et des moûts. Paris, 2009. p.368.

RIZZON, L.A. (Ed.) Metodologia para análise de vinho. Brasília: Embrapa Informação Tecnológica, 2010. p.120.
ROSIER, J.P. Vinhos de altitude: características e potencial na produção de vinhos finos brasileiros. Informe Agropecuário, Belo Horizonte, v.27, n.234, p.105-110, 2006.

SANTOS, H.G.; JACOMINE, P.K.T.; ANJOS, L.H.C.; OLIVEIRA, V.A.; LUMBRERAS, J.F.; COELHO, M.R.; ALMEIDA, J.A.; CUNHA, T.J.F.; OLIVEIRA, J.B. Sistema brasileiro de classificação de solos. 3 .ed. Brasília: Embrapa, 2013. p.353.

SAS Institute. Statistical analysis system. Versão 9.1.3. Cary, 2003.

SENTELHAS, P.C. Aspectos climáticos para a viticultura tropical. Informe Agropecuário, Belo Horizonte, v.19, n.194, p.9-14, 1998.

SINGLETON, V.L.; ROSSI, J.A. Colorimetry of total phenolics with phosphomolybdic - phosphotunestic acids reagents. American Journal of Enology and Viticulture, Davis, v.16, n.3, p.144-158, 1965.

SOIL SURVEY STAFF. Keys to soil taxonomy. $12^{\text {th }}$ ed. Washington: USDA-NRCS, 2014.

TONIETTO, J.; MANDELLI,F. Uvas para processamento em regiões de clima temperado. Bento Gonçalves: Embrapa Uva e Vinho, 2003. Disponível em: $<\underline{\text { https:// }}$ sistemasdeproducao.cnptia.embrapa.br/FontesHTML/ Uva/UvasViniferasRegioesClimaTemperado/colheita. $\underline{\mathrm{htm}}>$. Acesso em: 11 jan. 2018.

UBALDE, J.M.; SORT, X.; ZAYAS, A.; POCH, R.M. Effects of soil and climatic conditions on grape ripening and wine quality of Cabernet Sauvignon. Journal of Wine Research, Davis, v.21, n.1, p.1-17, 2010.

VAN GENUCHTEN, M.T. A closed form equation for predicting the hydraulic conductivity of unsaturated soils. Soil Science Society of America Journal, Madison, v.44, p.892-898, 1980.

VAN LEEUWEN, C.; FRIANT, P.; CHONÉ, X.; TREGOAT, O.; KOUNDOURAS, S.; DUBOURDIEU, D. Influence of climate, soil, and cultivar on terroir. American Journal of Enology and Viticulture, Davis, v.55, p.207-217, 2004. Disponível em: $<$ https://pdfs. semanticscholar.org/c645/887e854244794db9c201995e 19a12cb7bcbd.pdf>. Acesso em: 7 nov. 2017. 
VAN LEEUWEN, C.; SEGUIN, G. Incidences de l'alimentation en eau de la vigne appréciée par l'état hydrique du feuillage, sur le développement de l'appareil végétatif et la maturation du raisin. Journal International de la Science de la Vigne et du Vin, Davis, v.28, p.81110, 1994.

VAN LEEUWEN, C.; SEGUIN, G. The Concept of Terroir in Viticulture. Journal of Wine Research, Davis, v.17, n.1, p.1-10, 2006. Disponível em: $<$ http://www. pawinegrape.com/uploads/PDF\%20files/Documents/ Articles/vanLeeuwenandSeguin2006.pdf $>$. Acesso em: 6 mar. 2017.

VAN LEEUWEN, C.; TREGOA, O.; CHONÉ, X.; BOIS, B.; PERNET, D.; GAUDILLÈRE, J.P. Vine water status is a key factor in grape ripening and vintage quality for red Bordeaux wine. How can it be assessed for vineyard management purposes? Journal International des Sciences de la Vigne et du Vin, Davis, v.43, n.3, p.121134, 2009.

VAN LEEUWEN, C.; TREGOAT, O.; CHONÉ, X.; JAECK, M.E.; RABUSSEAU, S.; GAUDILLERE, J.P. Le suivi du régime hydrique de la vigne et son incidence sur la maturation du raisin. Bulletin de l'O.I.V, Paris, v.76, p.367-379, 2003.
WARMLING, M.I. Variabilidade espacial do solo e efeito da safra sobre a produtividade e composição da uva e do vinho no Planalto Catarinense. 2017. 95 f. Dissertação (Mestrado em Ciência do Solo) - Universidade do Estado de Santa Catarina, Florianópolis, 2017.

WURZ, D.A. Desempenho viti-enológico das variedades Cabernet Sauvignon e Sauvignon Blanc em regiões de altitude em função da época de desfolha. 2016. 146 f. Dissertação (Mestrado em Produção Vegetal) Universidade do Estado de Santa Catarina, Florianópolis, 2016.

WUTKE, E.B.; TERRA, M.M.; PIRES, E.J.P.; COSTA, F.; SECCO, I.L.; RIBEIRO, I.J.A. Influência da cobertura vegetal do solo na qualidade dos frutos de videira 'Niagara Rosada'. Revista Brasileira de Fruticultura, Jaboticabal, v.27, n.3, p.434-439, 2005.

ZOCCHE, R.G.S. Potencial enólogo de uvas Tannat, Cabernet Sauvignon e Merlot produzidas no município de Bagé-RS. 2009. 113 f. Tese (Doutorado em Ciências) - Universidade Federal de Pelotas, Pelotas, 2009. 